\title{
BROWN, W. Undoing the Demos: Neoliberalism's Stealth Revolution. New York: Zone Books, 2015
} Alexandre Marinho Pimenta

Um dos últimos livros da professora de Ciência Política da Universidade da Califórnia, Wendy Brown, Undoing the Demos: Neoliberalism's Stealth Revolution, trata de uma das questóes mais significativas e preocupantes do jovem século XXI: os processos de fenecimento da democracia. A estratégia de Brown é revisitar e retificar o entrelaçamento entre neoliberalização e desdemocratização. Ou, para usar sua original definição, analisar a "revolução silenciosa” realizada pelo neoliberalismo contra a democracia.

Mas a autora náo se limita a destrinchar a dinâmica de tal crise da democracia. No início do livro, a autora sinaliza ao leitor que sua recente obra será também um espaço para a discussão dos dilemas atuais da intervenção e da imaginação política democrática. Sendo assim, a avaliação da obra deve ser dupla, unindo estratégias e força argumentativas da pesquisadora à pertinência prático-política de sua construção teórica e propostas explícitas.

Entendendo democracia no sentido mais "aberto" e "cru" possível, próximo à conotação geral de autogoverno do povo (BROWN, 2015, p. 20) e uma pretensão a isso, Brown não vê o governo do demos como um destino inevitável da história humana ou mesmo um caminho seguro para o paraíso na Terra. Acima de tudo, trata-se “[...] uma forma vazia que pode

\footnotetext{
Mestre em Sociologia e Doutorando em Ciência Política pela Universidade de Brasília. Distrito Federal, Brasil. E-mail: alexmpimenta!@gmail.com.
}

$(\infty)$ EY
Direito autoral e licença de uso: Este artigo está licenciado sob uma Licença Creative Commons. Com essa licença você pode compartilhar, adaptar, para qualquer fim, desde que atribua a autoria da obra, forneça um link para a licença, e indicar se foram feitas alterações. 
ser preenchida por uma variedade de conteúdos ruins e instrumentalizada por propósitos que vão desde o nacionalismo xenofóbico ao colonialismo racial, do heterossexismo ao capitalista hegemônico" (BROWN, 2015, p. 202) ${ }^{2}$. Por tais razóes, a questáo democrática deve ganhar mais centralidade no debate público, inclusive nos programas de esquerda.

A divisão do livro se dá em duas partes principais: Razão neoliberal e vida política e Disseminando a razão neoliberal. Ademais, há um instigante epílogo intitulado como Perdendo a democracia crua e a inversão da liberdade em sacrifício - para nós, como veremos, o ponto forte do livro.

A estadunidense parte da tese de que o neoliberalismo não é apenas uma modalidade de capitalismo, mas "[...] uma forma peculiar de razão que configura todos os aspectos da existência em termos econômicos" (BROWN, 2015, p. 17); que nos interpela a agir como agentes de mercados mesmo em situaçôes e contextos de não mercado.

Para Brown, tal configuração se choca com os elementos e os valores básicos da democracia, da esfera pública e da política em si. Por isso, o futuro da democracia em geral, ou melhor, até mesmo o futuro da limitada democracia liberal-burguesa, está em jogo com a disseminação da razão neoliberal, que não só coloniza como destrói todas suas instituiçôes, normas e condutas. O governo do/pelo econômico tem sido uma forma de "desmonte da democracia 'por dentro"” (BROWN, 2015, p. 18). E mais: limita nossa forma de vida a um confinamento no "reino das necessidades", uma espécie de "pré-história” para Marx (BROWN, 2015, p. 43).

Durante todo o livro, vê-se um constante diálogo com a obra de um dos principais pensadores do século XX que possibilitou essa noção alargada de neoliberalismo e se tornou essencial para diversos desdobramentos contemporâneos da teoria crítica: Foucault, sobretudo em sua fase genealógica. Na primeira parte do livro, Brown se concentra no curso sobre O Nascimento da Biopolítica (1978-1979). Já na segunda parte, lança mão do conceito de racionalidade política como instrumento para refletir a disseminação e hegemonização da razão neoliberal, sobretudo nas novas formas de gestão, jurisdição e educação.

2 As citações desta resenha são de minha tradução. 
A “economização" da vida política e de outras dimensões da vida humana no neoliberalismo é tematizada pelo filósofo francês, como lembra Brown, através de uma concomitante diferenciação e radicalização frente às formulações clássicas da economia política sobre uma razão de Estado mínimo. Esse movimento aponta, em última instância, para a produção de um homo oeconomicus singular: um sujeito que age como empresário de si mesmo; o ser humano como capital humano. O neoliberalismo inauguraria, para Foucault, uma nova arte de governar, baseada na regulação da sociedade e Estado pelas lógicas mercantis de empreendimento, produtividade e competitiva - tornados esses valores e consensos consolidados institucionalmente.

Contudo, a autora busca atualizar tais enunciados. Em um cenário de pós-financeirização e sua respectiva crise, Brown afirma que o sujeito-empresa fora substituído pelo sujeito enquanto um portfólio de investimentos; a liberdade e interesse individual, pelo sacrifício e pelas exigências macroeconômicas; o governo pela governança e uma (perversa) responsabilização; o estado nacional pelas instâncias transnacionais... E assim por diante. O sujeito neoliberal, de uma forma geral, escancara seu caráter servil, quanto mais sua racionalidade se torna acachapante.

Brown também enfrenta a indiferença de Foucault frente à democracia (para ela, encarnada na figura do homo politicus) e o capital em si. Essas duas lacunas no edifício foucaultiano da biopolítica, em grande parte são tributárias da oposição do francês ao marxismo. "Foucault desviou seu olhar do capital como uma força histórica e social. [...] No entanto, capital e capitalismo não são redutíveis a uma ordem de razão" (BROWN, 2015, p. 75). Para a autora, a teoria marxista trata de imperativos sistêmicos do capital para além do nível discursivo-institucional, que devem ser consideradas na análise formas dominantes de racionalidade e governo em determinado contexto histórico. Da mesma forma, tal teoria consegue equacionar as promessas ideológicas de liberdade e democracia e os regimes de dominação burguesas realmente existentes, um dos pontos cegos de Foucault.

Todavia, para o objetivo do livro, não se trata de "[...] corrigir Foucault com Marx, mas trazer certas dimensóes da análise de Marx do 
capitalismo à apreciação foucaultiana da razão neoliberal para gerar uma rica explicação da desdemocratização neoliberal” (BROWN, 2015, p. 77).

Essa crítica construtiva da autora, ao mesmo tempo em que tornam mais complexa e dinâmica as formulaçôes foucaultianas, aprofundam, paradoxalmente, a gravidade e a paralisia de nosso momento histórico. Isso porque, no exato momento em que anuncia o homo politicus, que se contrapóe ao homo juridicus e homo legalis de Foucault, e este se mostra como ponta de resistência à lógica do capital à racionalidade política do neoliberalismo, ela denuncia, no mesmo ato, sua morte prematura. Nasce enquanto vítima mortal:

[...] o homo politicus é a vítima mais importante da ascensão da razão neoliberal, sobretudo porque sua forma democrática seria a principal arma contra a consolidação de tal razão como uma racionalidade dominante, o recurso para se opor com um conjunto de reivindicações e outra visão da existência. (BROWN, 2015, p. 87).

A revolução em tela é silenciosa não apenas pela disseminação surda de uma racionalidade, mas também porque ocorre "[...] em nome do livre mercado, dos países e homens livres - mas destrói a base de liberdade para exercício da soberania dos estados e sujeitos" (BROWN, 2015, p. 108). A soberania política de todos é reduzida à razão neoliberal que lhes exigem constantes sacrifícios.

Outro paradoxo, este assumido pela autora, é o fato de encarar o neoliberalismo como onipresente enquanto razão normativa, apesar de desunificado e cuja racionalidade política não absorve todos os discursos. Este recurso pode ser interessante enquanto orientação metodológica, possibilitando uma ferramenta analítica que consiga abarcar tempos, regióes e características diversas sem cair em um particularismo fragmentador. Todavia, ao longo do livro, essa definição nos coloca frente a um estranho ente quase metafísico (e de traços muito estadunidenses), cuja resistência, em mais um nível, também parece estar bloqueada por completo. Ente este cuja disseminação aparece descrita, por meio de diversos caminhos e temporalidades, mas não explicada. Ou seja, vemos em quais pontos a 
racionalidade política neoliberal é antidemocrática. Mas por quais motivos a nova racionalidade derrotou a anterior? Onde está sua força de atração/ sedução? Qual a relação entre o nível discursivo e o não discursivo, como a lógica do capital enunciada por Brown? Esta poderia explicar algo sobre como se ganhou as almas e os coraçóes visados por Thatcher?

Essas perguntas sequer são realizadas de fato. De fato, pois não se integram à argumentação da autora de forma consolidada. Em seu epílogo, trata rapidamente das sedutoras promessas da política econômica "trickle-down” dos anos 1980, mas para explicar que estas já não existem (BROWN, 2015, p. 213). Ao tratar das agricultura iraquiana pós-invasão estadunidense, apenas indiretamente nos diz como a razão neoliberal chegou lá (pelas armas) e por quais motivos (disputa imperialista, assalto de recursos e regióes estratégicas, interesses monopolistas). O link entre lógica do capital e razão neoliberal não é problematizado de frente. Aliás, para não ser injusto, no final do capítulo em questão, lemos: "A governança neoliberal facilita uma fusão mais aberta e eficaz do poder político e econômico, que elimina em grande parte o escândalo da corrupção, uma vez que apaga as diferenças nas metas e na governança entre Estados e capital" (BROWN, 2015, p. 150).

Mas não avança muito mais que isso; então, logo à frente, utiliza o mesmo exemplo iraquiano para reforçar Foucault contra Marx, já que se está diante de uma determinação jurídica (a consolidação da racionalidade neoliberal no Iraque foi mudanças legislativas internas) e não econômica.

O contrapeso da teoria marxista não se apresenta como se pretendia inicialmente. Ao contrário, já nasce morto, como o homo politicus durante a exposição do livro. A impressão dada é de uma racionalidade que atua na desarticulação das bases da democracia e de uma cidadania plena, porque isso condiz com sua essência-natureza: anônima, autônoma e antidemocrática. $\mathrm{O}$ mercado exige sacrifício, mas parece não se beneficiar com isso, nem este em si, muito menos seus agentes. Chegamos à seguinte definição circular: o poder se exerce como poder porque é poder.

Náo que falte à autora um ingênuo "otimismo". Mas parece que suas lentes teórico-metodológicas não possibilitam enxergar de forma mais 
realista as contradiçôes e as fissuras do mundo social e político e as novas formas de resistência que tanto pretende analisar. Ora, os indivíduos "dispensáveis e desprotegidos” (BROWN, 2015, p. 134) da perversa responsabilização neoliberal, decorrente de uma inversão do contrato social, em nenhuma instância se voltam contra o homo oeconomicus, ainda que não seja sob a forma de um homo politicus? Além disso, o fenecimento da democracia e o bloqueio da política, por diversas vezes mencionados no livro, mostram-se fatos já consumados, invalidando a motivação e a promessa inicial do livro, somente restando ao pensamento assumir a forma de uma melancólica coruja de Minerva.

Concordamos nesse ponto com Wacquant quando critica os limites da abordagem foucaultiana sobre o neoliberalismo (na qual inclui Wendy Brown). Para ele, tal adordagem é “[...] excessivamente ampla e promíscua, superpovoada por uma proliferaçáo de instituiçóes, todas aparentemente infectadas pelo vírus neoliberal, e descamba para um solipsismo crítico" (WACQUANT, 2012, p. 507). Criticando também o que chama de concepção economicista, o autor, a partir de Bourdieu, vê a importância de se colocar a centralidade da reconfiguraçáo do Estado e da dinâmica classista na análise do neoliberalismo. Proposta, no entanto, que não é nosso objetivo aqui analisar, mas que converge em alguns aspectos à crítica imanente aqui realizada.

Por fim, temos um internamente contraditório epílogo, mas também instigante e forte - exatamente por ser contraditório, também, com várias teses problemáticas do livro. No início, temos uma Wendy Brown com pretensões mais modestas, resumindo sua obra apenas como uma análise da gramática e dos termos da racionalidade neoliberal (BROWN, 2015, p. 201), já que pensar quais formas de democracia e resistência podem existir sobre a hegemonia desta não faz tanto sentido: sua onipresença apenas pode ser vencida com advento de outra racionalidade sociopolítica. Sua derrota somente virá com sua derrota. A argumentação circular retorna. Mas logo à frente, a nosso ver, o ponto forte do livro, a autora desenvolve a noção de "sacrifício compartilhado", um complemento da racionalidade neoliberal que a aproxima da lógica fascista. Recorrendo à antropologia, analisa as dinâmicas psíquicas que envolvem o sacrifício. A noção se mostra, então, muito frutífera e condiz com as diversas experiências de austeridade 
ocorridas desde o advento da Grande Recessão. Mais ainda: aqui Brown enxerga, pela primeira e única vez, possíveis contradiçóes e saídas da onipresença já comentada. A lógica do sacrifício pode inverter-deslocar os polos da relação do sacrifício além de ter em seu interior uma promessa de restauração, reequilíbrio de forças e harmonia. A autora se permite pensar: e se o descontentamento frente ao engodo sacrifício compartilhado neoliberal se canalizar para uma força política buscando uma alternativa?

De qualquer forma, apesar dos desníveis entre início, meio e fim (epílogo), ainda se está diante de uma obra pertinente e rica. Ainda que náo se desenvolva, de uma maneira mais prolongada, um diálogo com teóricos contemporâneos da desdemocratização e da recente articulação entre Marx e Foucault (autores como Rancière, Balibar, Agamben, Dardot e Laval aparecem apenas de passagem no texto), as competentes incursóes nos teóricos clássicos já valem a leitura.

\section{Referências}

BROWN, Wendy. Undoing the Demos: Neoliberalism's Stealth Revolution. New York: Zone Books, 2015.

WACQUANT, Loïc. Três etapas para uma antropologia histórica do neoliberalismo realmente existente. Cad. CRH, Salvador, v. 25, n. 66, p. 505-518, dez. 2012. 